In cooperation with the Louisiana Department of Transportation and Development

\title{
Water Resources of Webster Parish
}

\section{Introduction}

In 2005, about 9.52 million gallons per day (Mgal/d) of water were withdrawn in Webster Parish, Louisiana (fig. 1), including about $9.33 \mathrm{Mgal} / \mathrm{d}$ from groundwater sources and $0.19 \mathrm{Mgal} / \mathrm{d}_{\text {from surface-water sources }}{ }^{1}$ (table 1). Publicsupply use accounted for about 70 percent of the total water withdrawn. Other categories of use included industrial, rural domestic, livestock, general irrigation, and aquaculture

${ }^{1}$ Tabulation of numbers in text and tables may result in different totals because of rounding; nonrounded numbers were used for calculation of totals. (table 2). Water-use data collected at 5-year intervals from 1960 to 2005 indicate water withdrawals in Webster Parish decreased substantially from 1970 to 1980; surface-water withdrawals for industrial use decreased from about 37 to $0 \mathrm{Mgal} / \mathrm{d}$ because of a paper mill closure in 1979. From 1980 to 2000, total water withdrawals in the parish ranged from 7 to $8 \mathrm{Mgal} / \mathrm{d}$ (fig. 2).

This fact sheet summarizes basic information on the water resources of Webster Parish, La. Information on groundwater and surface-water availability, quality, development, use, and trends is based on previously published reports listed in the Selected References section.
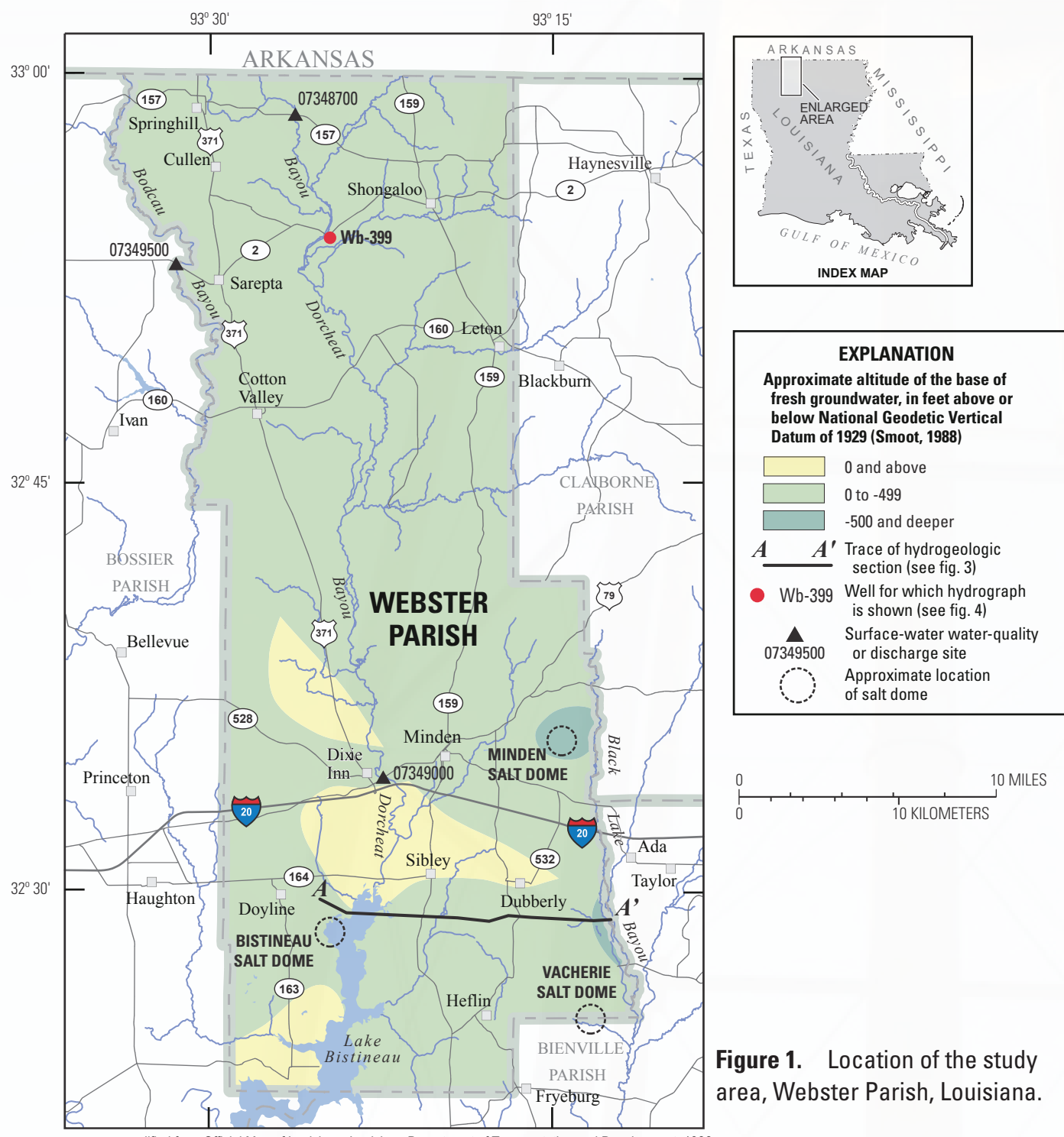

Base map modified from Official Map of Louisiana, Louisiana Department of Transportation and Development, 1986

Figure 1. Location of the study area, Webster Parish, Louisiana. 
Table 1. Water withdrawals, in million gallons per day, by source in Webster Parish, Louisiana, 2005 (modified from Sargent, 2007).

\begin{tabular}{lcc}
\hline \multicolumn{1}{c}{ Aquifer or surface-water body } & Groundwater & Surface water \\
\hline Upland terrace aquifer & 0.36 & - \\
Sparta aquifer & 7.44 & - \\
Carrizo-Wilcox aquifer & 1.53 & - \\
Miscellaneous streams & - & .19 \\
Total & 9.33 & 0.19 \\
\hline
\end{tabular}

Table 2. Water withdrawals, in million gallons per day, by category in Webster Parish, Louisiana, 2005 (modified from Sargent, 2007).

\begin{tabular}{lccc}
\hline \multicolumn{1}{c}{ Category } & Groundwater & $\begin{array}{c}\text { Surface } \\
\text { water }\end{array}$ & Total \\
\hline Public supply & 6.71 & 0.00 & 6.71 \\
Industrial & 2.17 & .00 & 2.17 \\
Rural domestic & .37 & .00 & .37 \\
Livestock & .02 & .16 & .17 \\
General irrigation & .00 & .04 & .04 \\
Aquaculture & .06 & .00 & .06 \\
Total & 9.33 & 0.19 & 9.52 \\
\hline
\end{tabular}

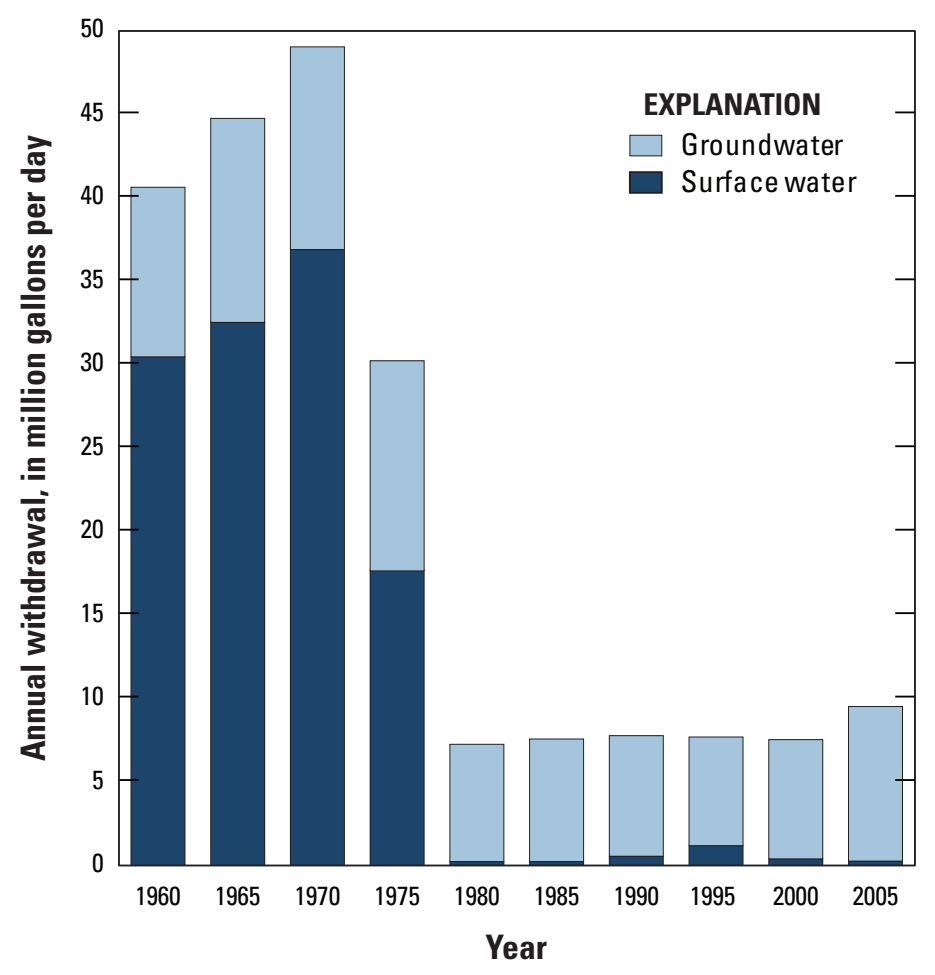

Figure 2. Water withdrawals in Webster Parish, Louisiana, 1960-2005.

\section{Groundwater Resources}

The primary groundwater resources of Webster Parish, from near surface to deepest, include the upland terrace, Sparta, and Carrizo-Wilcox aquifers (fig. 3). Fresh groundwater (water with a chloride concentration of 250 milligrams per liter $[\mathrm{mg} / \mathrm{L}]$ or less) is available throughout most of the parish at depths generally ranging from about 0 feet (ft) above the National Geodetic Vertical Datum of 1929 (NGVD 29) (sea level) to about $300 \mathrm{ft}$ below NGVD 29. The base of freshwater can be much deeper locally. In the vicinity of the Minden salt dome, located about 4 miles (mi) east of the town of Minden, the base of freshwater is about $900 \mathrm{ft}$ below NGVD 29. The base of fresh groundwater is affected by the relation of terrain to regional and local geologic and hydrologic conditions or features such as local faults, structural domes, and drainage into streams and other aquifers. Groundwater hydrology is also affected locally by the Bistineau, Minden, and Vacherie salt domes, which are located in southern Webster Parish (fig. 1).

State well-registration records listed 959 active water wells in Webster Parish in 2009, including 728 domestic, 134 public-supply, 55 industrial, and 42 irrigation wells. In 2005, groundwater withdrawals for various categories of use included public-supply, industrial, rural-domestic, livestock, and aquaculture (table 2).

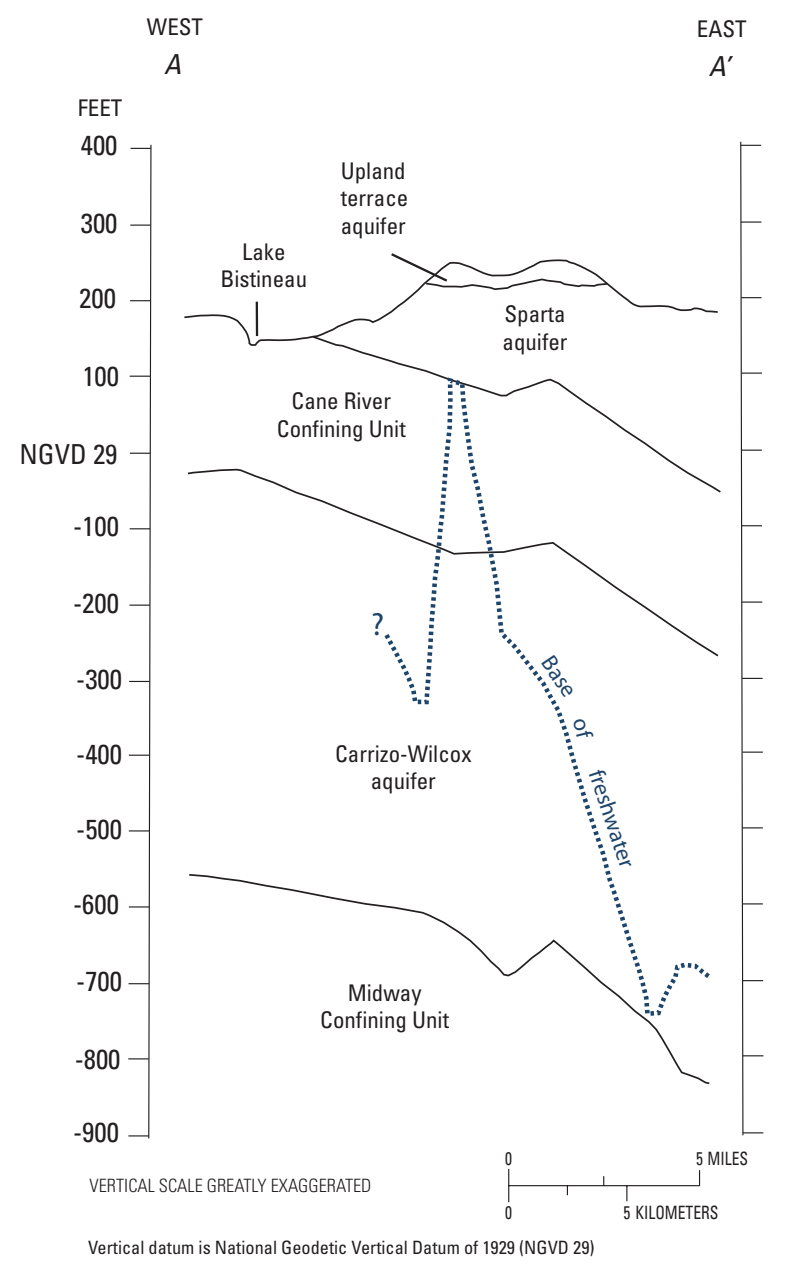

Figure 3. Generalized west-to-east hydrogeologic section showing aquifer and confining-unit intervals in Webster Parish, Louisiana (modified from Ryals, 1982, pl. 3). Individual sand and clay layers not shown. Trace of section shown on figure 1. 


\section{Upland Terrace Aquifer}

In Webster Parish, terrace deposits outcrop over much of the western half and southern third of the parish and along alluvial valleys throughout the parish. Terrace deposits in Webster Parish are generally less than 100-ft thick and consist of clay, silt, and fine sand grading to coarse sand and gravel at the base. The principal source of recharge to the terrace deposits in northern Louisiana is precipitation. The upland terrace aquifer comprises water-bearing sands and gravels within the terrace deposits.

State well-registration records listed 65 active wells screened in the upland terrace aquifer in Webster Parish in 2009, including 48 domestic, 8 public-supply, 5 industrial, and 4 irrigation wells. Depths of these wells ranged from 14 to $120 \mathrm{ft}$ below land surface, with a median depth of $75 \mathrm{ft}$. Yields from wells screened in the upland terrace aquifer in Webster Parish have reportedly ranged from 1 to 1,200 gallons per minute ( $\mathrm{gal} / \mathrm{min})$. In 2005, withdrawals from the upland terrace aquifer in Webster Parish were about $0.36 \mathrm{Mgal} / \mathrm{d}$ and included about $0.29 \mathrm{Mgal} / \mathrm{d}$ for public-supply, $0.05 \mathrm{Mgal} / \mathrm{d}$ for rural-domestic, $0.01 \mathrm{Mgal} / \mathrm{d}$ for livestock, and $0.01 \mathrm{Mgal} / \mathrm{d}$ for aquaculture purposes.

\section{Sparta Aquifer}

The Sparta aquifer is present throughout Webster Parish except in the southwestern corner. The aquifer consists of 400 to $500 \mathrm{ft}$ of nonmarine massive sands and silty sands. Within the aquifer are silty shales with occasional lignites and lignitic shales. The Sparta aquifer outcrops (or subcrops) across most of western and southern Webster Parish and dips gently to the northeast. The base of the aquifer is about $50 \mathrm{ft}$ above NGVD 29 near the town of Sibley in the southern part of the parish and about $300 \mathrm{ft}$ below NGVD 29 in the northeastern part of the parish, near the Webster and Claiborne Parish line. The aquifer is recharged by precipitation and local recharge from the overlying upland terrace aquifer. Groundwater flow is generally to the east-northeast.

In 2007, water levels in the Sparta aquifer in Webster Parish ranged from about $180 \mathrm{ft}$ above NGVD 29 in the northwest corner of the parish to about $120 \mathrm{ft}$ above NGVD 29 in the northeast corner of the parish. Water levels were less than $120 \mathrm{ft}$ above NGVD 29 in the Minden area, where withdrawals have created a small cone of depression. Water levels in the Sparta aquifer in Webster Parish generally fluctuate a few feet annually, as shown in the hydrograph of well Wb-399, located in northern Webster Parish (fig. 4).

State well-registration records listed 376 active wells screened in the Sparta aquifer in Webster Parish in 2009, including 227 domestic, 88 public-supply, 39 industrial, and 22 irrigation wells. Depths of these wells ranged from 27 to $656 \mathrm{ft}$ below land surface, with a median depth of $203 \mathrm{ft}$. Yields from wells screened in the Sparta aquifer in Webster Parish have reportedly ranged from 1 to $1,300 \mathrm{gal} / \mathrm{min}$. In 2005, groundwater withdrawals from the Sparta aquifer in Webster Parish totaled about 7.44 Mgal/d (table 1) and included about 5.11 Mgal $/ \mathrm{d}$ for public-supply, 2.17 Mgal/d for industrial, $0.13 \mathrm{Mgal} / \mathrm{d}$ for rural-domestic, $0.01 \mathrm{Mgal} / \mathrm{d}$ for livestock, and $0.02 \mathrm{Mgal} / \mathrm{d}$ for aquaculture uses.

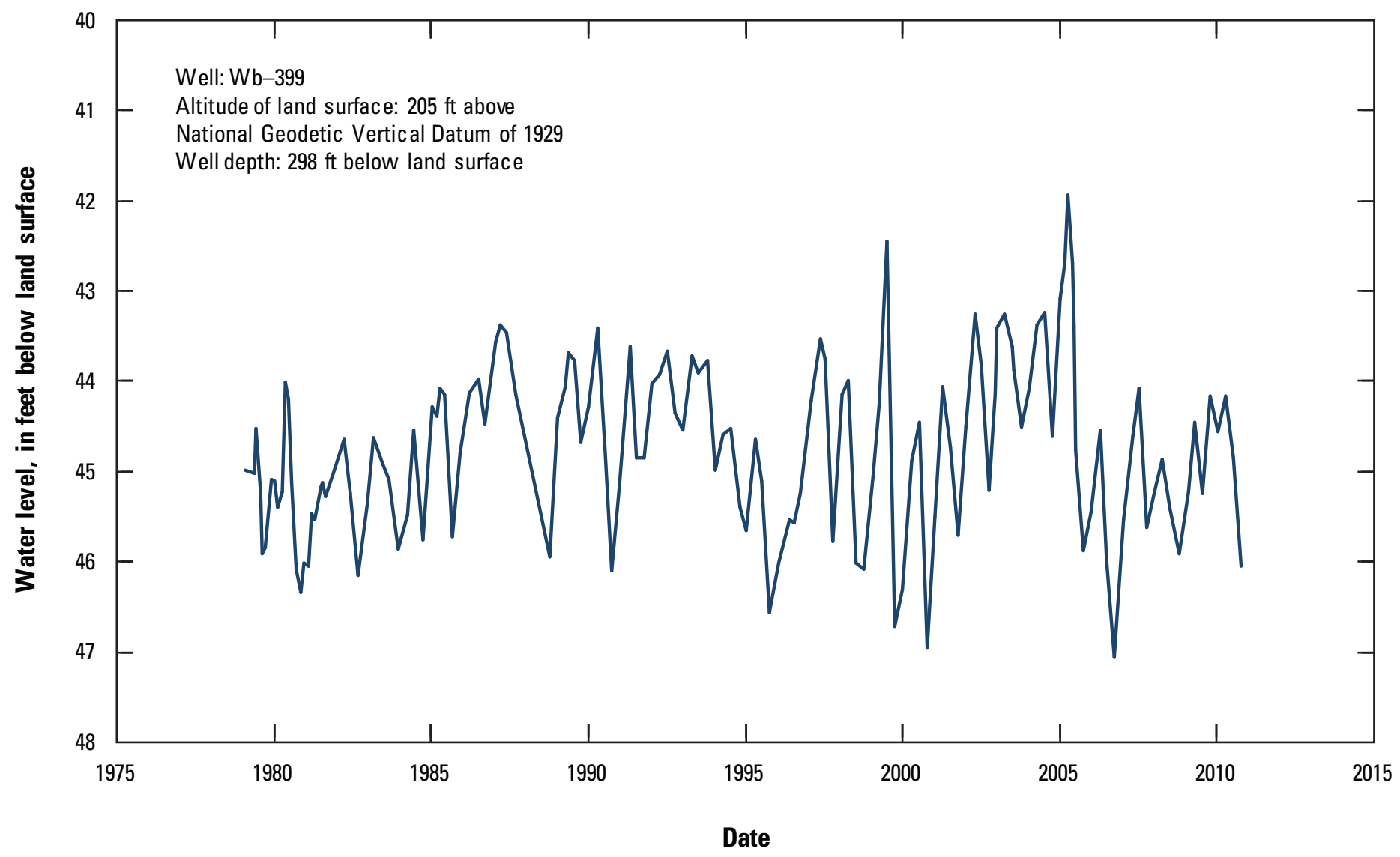

Figure 4. Water levels in well Wb-399 screened in the Sparta aquifer in Webster Parish, Louisiana (see fig. 1 for well location; U.S. Geological Survey, 2009). 
Table 3. Summary of selected water-quality characteristics for freshwater in the Sparta and Carrizo-Wilcox aquifers in Webster Parish, Louisiana.

[Values are in milligrams per liter, except as noted. ${ }^{\circ} \mathrm{C}$, degrees Celsius; $\mathrm{PCU}$, platinum cobalt units; $\mu \mathrm{S} / \mathrm{cm}$, microsiemens per centimeter; $\mathrm{SU}$, standard units; $\mathrm{CaCO}_{3}$, calcium carbonate; $\mu \mathrm{g} / \mathrm{L}$, micrograms per liter; <, less than; NA, not applicable; SMCL, Secondary Maximum Contaminant Level established by the U.S. Environmental Protection Agency (2011)]

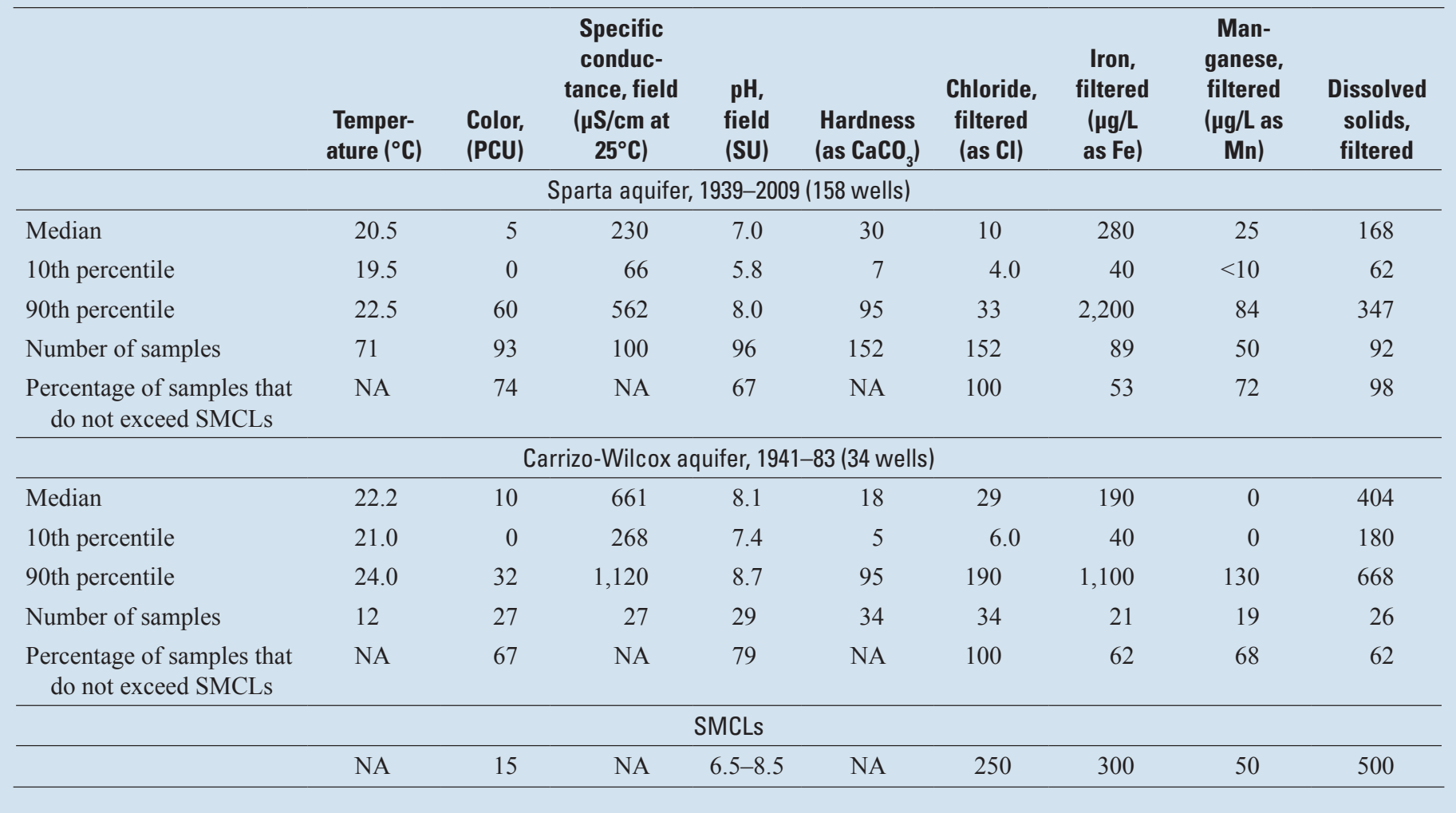

A statistical summary of selected water-quality characteristics for freshwater from 158 wells screened in the Sparta aquifer in Webster Parish is listed in table 3. Based on median values of constituents, freshwater from the aquifer is generally soft (60 mg/L or less as calcium carbonate) and does not exceed the U.S. Environmental Protection Agency's Secondary Maximum Contaminant Levels² (SMCLs) for drinking water for color, $\mathrm{pH}$, iron, manganese, and dissolved solids. Water in some areas, however, contains excessive amounts of iron or manganese.

\section{Carrizo-Wilcox Aquifer}

The Carrizo-Wilcox aquifer is composed of sands and gravels in the Carrizo Sand and Wilcox Group, which are hydraulically connected and considered to be a single aquifer. The Carrizo-Wilcox aquifer contains freshwater south of the town of Sibley and along the southwestern edge of Webster Parish (fig. 1). In this freshwater area, the total sand thickness of the aquifer generally ranges from less than 20 to about $90 \mathrm{ft}$. In the vicinity of the Minden salt dome, freshwater is present

\footnotetext{
${ }^{2}$ The SMCLs are nonenforceable Federal guidelines regarding cosmetic effects (such as tooth or skin discoloration) or aesthetic effects (such as taste, odor, or color) of drinking water. At high concentrations or values, health implications as well as aesthetic degradation might exist. SMCLs were established as guidelines for the States by the U.S. Environmental Protection Agency (1992).
}

in the Carrizo-Wilcox aquifer to a depth of about $900 \mathrm{ft}$ below NGVD 29 (fig. 1).

The aquifer receives recharge from precipitation where it outcrops (or subcrops) in the southwestern corner of Webster Parish and in neighboring Bossier Parish. In 1991, water levels in the Carrizo-Wilcox aquifer in Webster Parish ranged from about 60 to $160 \mathrm{ft}$ above NGVD 29. The lowest water levels occurred in southwestern Webster Parish at the town of Doyline, where pumping from the aquifer in the area has created a small cone of depression. Water movement in the aquifer in Webster Parish is radially towards the Doyline area.

State well-registration records listed 330 active wells screened in the Carrizo-Wilcox aquifer in Webster Parish in 2009, including 288 domestic, 27 public-supply, 8 industrial, and 7 irrigation wells. Depths of these wells ranged from 40 to $691 \mathrm{ft}$ below land surface, with a median depth of $234 \mathrm{ft}$. Yields from wells screened in the Carrizo-Wilcox aquifer in Webster Parish have reportedly ranged from 1 to $300 \mathrm{gal} / \mathrm{min}$. In 2005, groundwater withdrawals from the Carrizo-Wilcox aquifer in Webster Parish totaled about $1.53 \mathrm{Mgal} / \mathrm{d}$ (table 1) and included about $1.31 \mathrm{Mgal} / \mathrm{d}$ for public supply, $0.19 \mathrm{Mgal} / \mathrm{d}$ for ruraldomestic use, and $0.02 \mathrm{Mgal} / \mathrm{d}$ for aquaculture.

A statistical summary of selected water-quality characteristics for freshwater from 34 wells screened in the Carrizo-Wilcox aquifer in Webster Parish is listed in table 3. Based on median values of constituents, freshwater from the Carrizo-Wilcox aquifer is generally soft and does not exceed the 
SMCLs for color, $\mathrm{pH}$, iron, manganese, and dissolved solids; however, in some areas the water contains excessive amounts of iron, manganese, or dissolved solids.

\section{Surface-Water Resources}

In 2005, about $0.19 \mathrm{Mgal} / \mathrm{d}$ of surface water was withdrawn in Webster Parish, including about $0.16 \mathrm{Mgal} / \mathrm{d}$ for livestock and $0.04 \mathrm{Mgal} / \mathrm{d}$ for irrigation (table 2). Major surface-water resources in the parish include Bodcau Bayou, which is located along the northwestern parish line; Black Lake Bayou, which is located along the southeastern parish line; Bayou Dorcheat; and Lake Bistineau. In northwestern Webster Parish, the gaging station on Bodcau Bayou near Sarepta (station number 07349500; U.S. Geological Survey, 2008) (fig. 1) had an average discharge of 598 cubic feet per second $\left(\mathrm{ft}^{3} / \mathrm{s}\right)$ during 1939-92. Prior to its closure in 1979, a paper mill located near Springhill had withdrawn as much as $37 \mathrm{Mgal} / \mathrm{d}$ from Bodcau Bayou.

In the northern part of the parish, the gaging station on Bayou Dorcheat near Springhill (station number 07348700; U.S. Geological Survey, 2008) (fig. 1) had an average discharge of $599 \mathrm{ft}^{3} / \mathrm{s}$ during $1957-2008$. The highest daily mean discharge was $35,000 \mathrm{ft}^{3} / \mathrm{s}$ on April 28, 1958. There also was a period of 5 consecutive days in October of 1957 when there was zero discharge in the bayou. The drainage area at this site is about 605 square miles $\left(\mathrm{mi}^{2}\right)$. The floodplain of Bayou Dorcheat averages about $1.5 \mathrm{mi}$ in width and is characterized by narrow natural levees and an abundance of sloughs, cutoffs, and oxbow lakes. In the southern part of the parish, the gaging station on Bayou Dorcheat near Minden (station number 07349000; U.S. Geological Survey, 2008) (fig. 1) had an average discharge of $1,111 \mathrm{ft}^{3} / \mathrm{s}$ during October 1928-September 1931 and October 1936-September 1979, when discharge data were collected at the site. The highest daily mean discharge during these periods was $44,800 \mathrm{ft}^{3} / \mathrm{s}$ on May 1, 1958. The drainage area at this site is about $1,097 \mathrm{mi}^{2}$.

Water samples collected from Bayou Dorcheat near Springhill (station number 07348700; U.S. Geological Survey, 2008) during 1961-86 indicate the water is generally soft and slightly acidic. The $\mathrm{pH}$ of the water is generally slightly below the SMCL range of 6.5 to 8.5; concentrations of chloride and sulfate are generally below the SMCLs (table 4).

Lake Bistineau is a $26.9-\mathrm{mi}^{2}(17,200$-acre $)$ reservoir located in south-central Webster Parish that extends southward into Bienville and Bossier Parishes. Lake Bistineau has a volume of 120,000 acre- $\mathrm{ft}$, an average depth of $7 \mathrm{ft}$, and a maximum depth of $25 \mathrm{ft}$. Bayou Dorcheat is the primary tributary, and much of the lake in Webster Parish is populated by trees, which restrict boating in some areas.

Table 4. Summary of selected water-quality characteristics for Bayou Dorcheat (near Springhill) in Webster Parish, Louisiana, and Lake Bistineau (near Ringgold) in Bossier Parish, La.

[Values are in milligrams per liter, except as noted. ${ }^{\circ} \mathrm{C}$, degrees Celsius; $\mu \mathrm{S} / \mathrm{cm}$, microsiemens per centimeter; $\mathrm{SU}$, standard units; $\mu \mathrm{g} / \mathrm{L}$, micrograms per liter; $\mathrm{CaCO}_{3}$, calcium carbonate; NA, not applicable; - , no data; SMCL, Secondary Maximum Contaminant Level established by the U.S. Environmental Protection Agency (2011)]

\begin{tabular}{|c|c|c|c|c|c|c|c|c|c|}
\hline & $\begin{array}{c}\text { Specific } \\
\text { conduc- } \\
\text { tance, } \\
\text { field }(\mu S / \mathrm{cm} \\
\left.\text { at } 25^{\circ} \mathrm{C}\right)\end{array}$ & $\begin{array}{l}\text { Oxygen, } \\
\text { dissolved }\end{array}$ & $\begin{array}{l}\text { pH, } \\
\text { field } \\
\text { (SU) }\end{array}$ & $\begin{array}{l}\text { Hardness } \\
\left(\text { as } \mathrm{CaCO}_{3}\right)\end{array}$ & $\begin{array}{l}\text { Calcium, } \\
\text { filtered } \\
\text { (as Ca) }\end{array}$ & $\begin{array}{l}\text { Mag- } \\
\text { nesium, } \\
\text { filtered } \\
\text { (as Mg) }\end{array}$ & $\begin{array}{l}\text { Sodium, } \\
\text { filtered } \\
\text { (as Na) }\end{array}$ & $\begin{array}{c}\text { Chloride, } \\
\text { filtered } \\
\text { (as CI) }\end{array}$ & $\begin{array}{l}\text { Sulfate, } \\
\text { filtered } \\
\text { (as } \mathrm{SO}_{4} \text { ) }\end{array}$ \\
\hline \multicolumn{10}{|c|}{ Bayou Dorcheat, 1961-86' } \\
\hline Median & 448 & 6.4 & 6.3 & 58 & 18 & 4.2 & 68 & 110 & 7.2 \\
\hline 90th percentile & 1,160 & 9.9 & 7.0 & 140 & 40 & 10 & 230 & 340 & 17 \\
\hline Number of samples & 86 & 24 & 84 & 74 & 72 & 72 & 68 & 83 & 74 \\
\hline $\begin{array}{c}\text { Percentage of samples that } \\
\text { do not exceed SMCLs }\end{array}$ & NA & NA & 40 & NA & NA & NA & NA & 86 & 100 \\
\hline \multicolumn{10}{|c|}{ Lake Bistineau, 1943-70² } \\
\hline Number of samples & 12 & - & 19 & 13 & 12 & 12 & 12 & 20 & 19 \\
\hline $\begin{array}{l}\text { Percentage of samples that } \\
\text { do not exceed SMCLs }\end{array}$ & NA & NA & 32 & NA & NA & NA & NA & 100 & 100 \\
\hline \multicolumn{10}{|c|}{ SMCLs } \\
\hline & NA & NA & $6.5-8.5$ & NA & NA & NA & NA & 250 & 250 \\
\hline
\end{tabular}

${ }^{1}$ Station number 07348700 (U.S. Geological Survey, 2011; specific data at http://nwis.waterdata.usgs.gov/la/nwis/qwdata/?site_no=07348700).

${ }^{2}$ Station number 07349250 (U.S. Geological Survey, 2011; specific data at http://nwis.waterdata.usgs.gov/la/nwis/qwdata/?site_no=07349250). 
Water samples collected from Lake Bistineau (station number 07349250; U.S. Geological Survey, 2011) at the southern end of the lake near the spillway (dam) during 1943-1970 indicate that the water is generally soft. The $\mathrm{pH}$ of the water is generally slightly below the SMCL range of 6.5 to 8.5 ; concentrations of chloride and sulfate are below the SMCLs (table 4).

\section{Selected References}

Martin, J.L., Hough, L.W., Raggio, D.L., and Sandberg, A.E., 1954, Geology of Webster Parish: Louisiana Department of Conservation Geological Bulletin 29, 252 p.

Ryals, G.N., 1982, Ground-water resources of the Arcadia-Minden area, Louisiana: Louisiana Department of Transportation and Development, Office of Public Works Water Resources Technical Report no. 28, 35 p.

Ryals, G.N., 1983, Regional geohydrology of the northern Louisiana salt-dome basin, part IV, hydraulic characteristics of the Wilcox- Carrizo: U.S. Geological Survey Water-Resources Investigations Report 83-4132, 9 p.

Sargent, B.P., 2007, Water use in Louisiana, 2005: Louisiana Department of Transportation and Development Water Resources Special Report no. 16, 133 p.

Shampine, W.J., 1971, Chemical, biological, and physical data for the major lakes and reservoirs in Louisiana: Louisiana Department of Public Works Basic Records Report no. 5, 98 p.

Smoot, C.W., 1988, Louisiana hydrologic atlas map no. 3: Altitude of the base of freshwater in Louisiana: U.S. Geological Survey Water- Resources Investigations Report 86-4314, 1 sheet.

U.S. Environmental Protection Agency, 1992, Secondary Drinking Water Regulations-guidance for nuisance chemicals: U.S. Environmental Protection Agency publication EPA 810/K-92001, 4 p., accessed September 28, 2011, at http://water.epa.gov/ drink/ contaminants/secondarystandards.cfm.

U.S. Environmental Protection Agency, 2011, 2011 Edition of the drinking water standards and health advisories: Washington, D.C., U.S. Environmental Protection Agency, Office of Water, EPA 820-R-11-002, 12 p., accessed September 2, 2011, at http://water.epa.gov/action/advisories/drinking/upload/ dwstandards2011.pdf.

U.S. Geological Survey, 2008, Water-resources data for the United States Water Year 2008: U.S. Geological Survey Water-Data Report WDR-US-2008, accessed November 6, 2009, at http:// wdr.water.usgs.gov/.

U.S. Geological Survey, 2009, Ground-water levels for Louisiana [data for USGS $325518093221901 \mathrm{~Wb}-399]$ : National Water Information System Web Interface, accessed November 20, 2009, at http://nwis.waterdata.usgs.gov/la/nwis/gwlevel/?site no $=325518093221901$.

U.S. Geological Survey, 2011, Water quality samples for Louisiana: National Water Information System Web Interface, accessed February 16, 2010, at http://nwis.waterdata.usgs.gov/la/ nwis/qwdata/.

\section{By Lawrence B. Prakken and Jason M. Griffith}

\section{For additional information, contact:}

Director, USGS Louisiana Water Science Center 3535 S. Sherwood Forest Blvd., Suite 120

Baton Rouge, LA 70816

E-mail: dc_la@usgs.gov

Fax: (225) 298-5490

Telephone: (225) 298-5481

Home Page: http://la.water.usgs.gov

This fact sheet was published by the U.S. Geological Survey, in cooperation with the Louisiana Department of Transportation and Development (DOTD). Thanks are given to Zahir "Bo" Bolourchi, Director, Water Resources Programs, Louisiana Department of Transportation and Development, who contributed to the content and design of the fact sheet. 